\title{
СТАТИСТИКА
}

UDC 311.17:336-027.511(477)

DOI: https://doi.org/10.32847/business-navigator.59-28

\begin{abstract}
Satyr Larysa,
Doctor of Sciences (Economics), Professor, Head of the Department of Entrepreneurship, Trade and Exchange Activity, Bila Tserkva National Agrarian University

Zadorozhna Ruslana, Candidate of Sciences (Economics), Associate Professor, Associate Professor of the Department of Entrepreneurship, Trade and Exchange Activity, Bila Tserkva National Agrarian University Novikova Victoria, Candidate of Sciences (Economics), Assistant of the Department of Information Systems and Technologies, Bila Tserkva National Agrarian University
\end{abstract}

Сатир Л.М., доктор економічних наук, професор, завідувач кафедри підприємництва, торгівлі та біржової діяльності, Білочерківський національний аграрний університет

Задорожна Р.П., кандидат економічних наук, доцент, доцент кафедри підприємництва, торгівлі та біржової діяльності, Білочерківський національний аграрний університет

Новікова В.В., кандидат економічних наук, асистент кафедри інформаційних систем і технологій, Білочерківський національний аграрний університет

\section{STATISTICAL ANALYSIS OF UKRAINIAN FINANCIAL SECTOR DEVELOPMENT IN THE GLOBAL CONTEXT}

Satyr Larysa, Zadorozhna Ruslana, Novikova Victoria. Statistical analysis of Ukrainian financial sector development in the global context. Nowadays, the financial sector plays an important role in the general progress of the economy, because of its impact on all spheres and branches of the economic system. The state and development of the financial sector of particular countries depend on global trends as well as local factors. The article analyzes regularities of temporal changes of value-added of Ukrainian sector of financial corporations in $2014-2018$ and shifts in its structure at the level of subsectors. The findings indicate that the financial corporations' sector has developed slower than the domestic economy as a whole. The main reason for such a situation is difficulties of the Ukrainian bank system lasting since the 2008 Global Financial Crisis. Regulatory activity of Ukrainian authorities aims to overcome problems of the financial sector and to enhance its competitiveness.

Key words: financial sector, financialization, System of National Accounts, statistical analysis, Strategy of Ukrainian Financial Sector Development until 2025.

Сатир Л.М., Задорожна Р.П., Новікова В.В. Статистичний аналіз розвитку фінансового сектору України в глобальному контексті. Сьогодні фінансовий сектор відіграє важливу роль у загальному прогресі економіки з огляду на його дедалі зростаючий вплив на всі сфери та галузі економічної системи. Стан та розвиток фінансового сектору окремих країн залежать як від глобальних тенденцій, найбільш яскравою з яких є діжиталізація фінансової діяльності, так і від локальних факторів, характерних для розвитку окремих економік. Трансформаційні зміни у функціонуванні фінансового сектору потребують адекватного відображення в офіційній статистиці, що досягається шляхом вдосконалення методологічної бази збирання та аналізу даних. Так, в четвертій версії міжнародного стандарту макроекономічної статистики, Системі національних рахунків 2008 року приділяється багато уваги врахуванню модифікацій діяльності фінансових 
установ. Зокрема, СНР-2008 дає більш чітке визначення фінансових послуг порівняно з СНР 1993 року. Також з огляду на диверсифікацію діяльності інституційних одиниць фінансового сектору було розширено його підсекторну структуру. За даними національних рахунків України проаналізовано закономірності динаміки доданої вартості вітчизняного сектору фінансових корпорацій за період 2014-2018 рр. та зрушення в її структурі на рівні підсекторів. Отримані результати свідчать про те, що український фінансовий сектор розвивається повільніше, ніж економіка в цілому: його додана вартість зросла на лише на $37,1 \%$, в той час додана вартість всієї економіки - на 118,3\%. При цьому частка підсекторів S122-S124 (корпорації, що приймають депозити, фонди грошового ринку та інвестиційні фонди негрошового ринку) зменшилась на 20,1 процентних пункти. Основною причиною такої ситуації є проблеми української банківської системи, не подолані з часів глобальної фінансової кризи 2008 року. Регулююча діяльність органів влади України спрямована на подолання проблем фінансового сектору та підвищення його конкурентоспроможності. Для розв'язання цих завдань на початку 2020 р. було схвалено Стратегію розвитку фінансового сектору України до 2025 року, успішна реалізація якої дозволить підвищити ефективність, прозорість та надійність вітчизняної фінансової системи у відповідності до кращих міжнародних стандартів.

Ключові слова: фінансовий сектор, фінансиалізація, система національних рахунків, статистичний аналіз, Стратегія розвитку фінансового сектору України до 2025 року.

Сатир Л.М., Задорожная Р.П., Новикова В.В. Статистический анализ развития финансового сектора Украины в глобальном контексте. В настоящее время финансовый сектор играет важную роль в общем прогрессе экономики, поскольку он влияет на все сферы и отрасли экономической системы. Состояние и развитие финансового сектора отдельных стран зависят как от мировых тенденций, так и от локальных факторов. В статье анализируются закономерности динамики добавленной стоимости сектора финансовых корпораций Украины в 2014-2018 гг. и изменения в ее структуре на уровне подсекторов. Результаты показывают, что сектор финансовых корпораций развивается медленнее, чем экономика Украины в целом. Основная причина этого - проблемы украинской банковской системы, длящиеся после мирового финансового кризиса 2008 года. Регулирующая деятельность украинских властей направлена на преодоление проблем финансового сектора и повышение его конкурентоспособности.

Ключевые слова: финансовый сектор, финансиализация, система национальных счетов, статистический анализ, Стратегия развития финансового сектора Украины до 2025 года.

Problem statement. Economic development over the last decades both on the global and national level has been controversial and driven by two main factors, namely financialization and digitalization. The first involves the growing importance of the financial sector, increasing volume of financial assets and extension of the range of financial instruments that have led to the emergence of the financialization phenomenon and new field of interdisciplinary research. The second powerful factor is the advancement of information technologies and their penetration into various fields of activity, including the financial sector. Financial innovations modify the global economic landscape as well as economies of particular countries and businesses.

Analysis of recent researches and publications. Authorities, scientists and professional community pay a lot of attention to the study of transformational processes in the financial sphere. Korneev [8] considers changes in the structure of the economy as an objective prerequisite for enhancing the role of the financial sector. Christophers [5] points out that nowadays, the financialization concept has shifted from the scientific periphery and become the mainstream of social-scientific disciplines. Mader, Mertens and van der Zwan state: "The concept of financialization has also expanded by transforming from a rather specialized term used by critical scholars into one that progressively used in the research across and beyond the social sciences and humanities" [10, p. 2]. Lagoarde-Segot favours introducing "financialization" term into the academic finance because of its significance [9, p. 113].

Financial liberalization reforms in most OECD and emerging countries at the beginning of the 1980s included liberalizing interest rates, foreign exchange and bond mar- kets, easing requirements for mandatory reserves of banks, deregulating banking activities and stock market trading $[9$, p. 114-115]. This has caused the vulnerability of financial markets in many respects [15]. Therefore, many authors $[1 ; 2 ; 6 ; 13 ; 14]$ believe that the global financial crisis of 2008 is comparable with the Great Depression of 1929 by its scope, severity and negative impact on the economy.

As Baranovskyi argues [3, p. 348], transformational processes in the financial sector influence, directly and indirectly, the economic system and other sectors as its parts.

A wide range of innovations is currently used in the financial sphere, namely, advanced analytics / artificial intelligence, robotics, biometrics, advanced encryption, advanced computing (quantum, edge, cloud, mobile), distributed ledger technology (blockchain) [19].

Task statement. The purpose of the research is to perform a statistical analysis of development features of Ukrainian financial sector under the framework of worldwide trends towards financialization and digitalization.

The statement of the basic material. Financialization and digitalization trends reinforce each other. Nowadays, these two phenomena are wide-known: growth of interest in using technological innovations in the financial sector (so-called "FinTech") has become exponential since 2015 (Figure 1).

Official statistics represent the ongoing changes in financial reality by improving the methodological base of data collection and analysis. Thus, the fourth version of the international standard for macroeconomic statistics "The System of National Accounts 2008 (2008 SNA)" devotes a lot of attention to reflecting different modifications in the financial sector. The 2008 SNA recognizes the finan- 


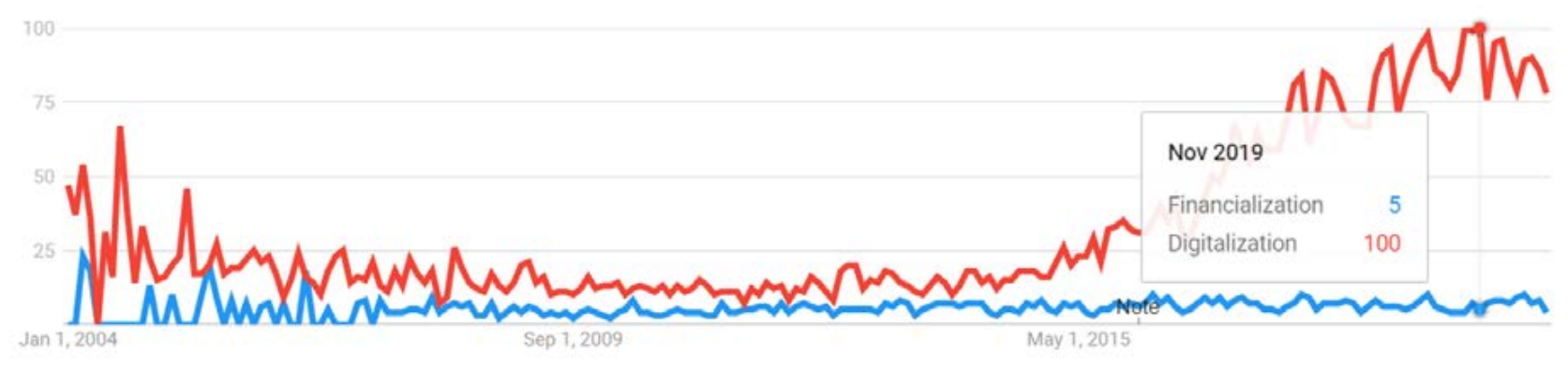

a) "Financialization" versus "Digitalization"

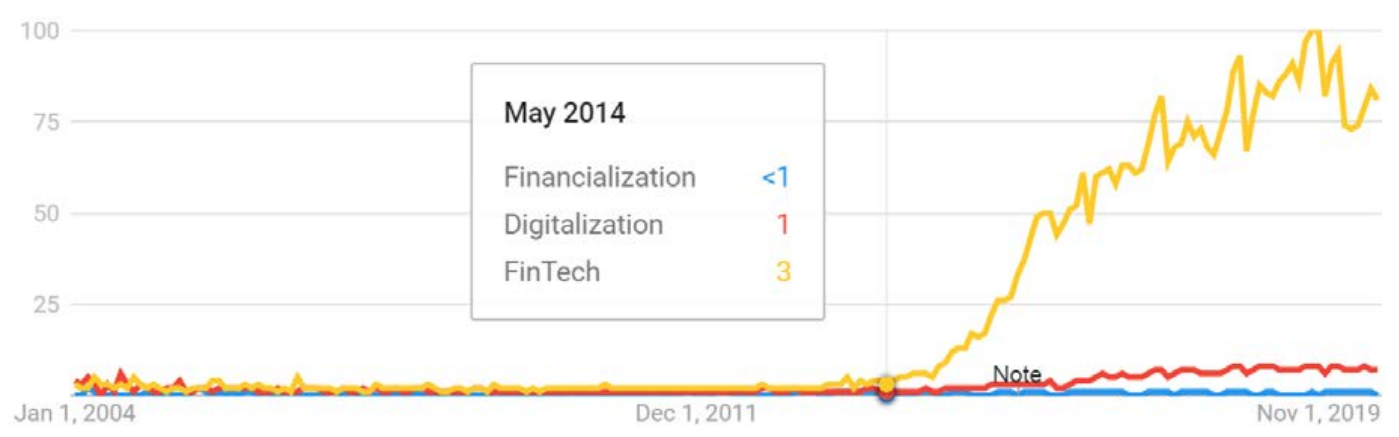

b) "FinTech" versus "Financialization" and "Digitalization"

Figure 1. Google Trends for the terms "Financialization", "Digitalization" and "FinTech"

Source: Google Trends, January 2004 - August 2020 (accessed 08.08.2020)

cial sector as one of the most rapidly changing parts of many economies and gives more explicit definition of the financial services in comparison with the 1993 SNA. The purpose of this broader definition is to trace the increasing range of financial services other than financial intermediation. Financial services include monitoring services, convenience services, liquidity provision, risk assumption, underwriting and trading services.

Diversification of activities of institutional units of the financial sector resulted in the necessity to expand its subsector structure (Table 1). This new more detailed set of subsectors renders a diversification of financial activity which has been observed during the last decades. Financial corporations are divided into nine subsectors based on the activity of the institutional units as well as the liquidity of its liabilities.

Analysis of the contribution of the financial corporations' sector to the gross value added of the Ukrainian economy according to new subsectors structure (Table 2) allows the authors to conclude that sector's value-added increased by $37.1 \%$ - from UAH 69423 million to UAH 79138 million over the period 2014 to 2018. But we need to mark its decline in 2015-2016 compared to 2014.

It should also be noted that the gross value added of the economy as a whole has significantly increased - by 118.3\% (from UAH 1382719 million to UAH 3018190 million) during the period under consideration.

The lagging of financial sector's growth rate of value-added from economy's growth rate resulted in decreasing of the sector's share in gross value added from $5.0 \%$ in 2014 to $3.1-3.2 \%$ in $2016-2018$. It points to the problems in the domestic financial corporations' activity caused by the financial crisis of 2008 as well as by dramatic events of contemporary Ukrainian history [10, p. 46-47].

The data also demonstrate noticeable changes which have occurred in the sub-sector structure of financial corporations' gross value added (Figure 2).

Changes in the subsector structure of the financial corporations' sector according to the 2008 SNA

\begin{tabular}{|l|l|}
\hline \multicolumn{1}{|c|}{ 1993 SNA } & \multicolumn{1}{c|}{ 2008 SNA } \\
\hline 1. Central bank & 1. Central bank (S121) \\
2. Other depository corporations & 2. Deposit-taking corporations except the central bank (S122) \\
3. Other financial intermediaries, except insurance & 3. Money market funds (MMFs) (S123) \\
corporations and pension funds & 4. Non-MMF investment funds (S124) \\
4. Financial auxiliaries & 5. Other financial intermediaries except insurance corporations and \\
5. Insurance corporations and pension funds & pension funds (S125) \\
& 6. Financial auxiliaries (S126) \\
& 7. Captive financial institutions and money lenders (S127) \\
& 8. Insurance corporations (S128) \\
9. Pension funds (S129)
\end{tabular}

Source: made by the authors relying on [18] 
Gross value added of the total Ukrainian economy* and financial corporations' sector**

Table 2 according to sub-sectors in 2014-2018, million UAH

\begin{tabular}{|c|c|c|c|c|c|c|c|c|c|}
\hline & \multirow{2}{*}{ S1 } & \multirow{2}{*}{ S12 } & \multicolumn{9}{|c|}{ in particular } \\
\cline { 4 - 10 } & & & $\mathbf{S 1 2 1}$ & $\mathbf{S 1 2 2 - S 1 2 4}$ & $\mathbf{S 1 2 5}$ & S126 & S127 & S128 & S129 \\
\hline 2014 & 1382719 & 69423 & 2570 & 50056 & 2394 & 1755 & 327 & 12242 & 79 \\
\hline 2015 & 1689387 & 65844 & 2095 & 38527 & 4697 & 2260 & 1658 & 16569 & 38 \\
\hline 2016 & 2023228 & 63400 & 1763 & 37151 & 4362 & 659 & 1288 & 17931 & 246 \\
\hline 2017 & 2519561 & 79138 & 1687 & 39859 & 8539 & 3906 & 2261 & 22561 & 325 \\
\hline 2018 & 3018190 & 95183 & 1695 & 49483 & 14059 & 3547 & 2539 & 23576 & 284 \\
\hline
\end{tabular}

Source: made by the authors relying on [16]

* total economy - S1,

** financial corporations' sector - S12.

At the beginning of the period under consideration, almost three quarters (72.1\%) of the sector's value-added was produced by the subsectors of Deposit-taking corporations except the central bank (S122), Money market funds (S123) and Non-MMF investment funds (S124), and Ukrainian commercial banks had the leading role. It needs to be stressed that prevailing of domestic banks constitutes a bank-centric model of Ukrainian financial market [7, p. 437-438; 17, p. 194].

But in 2018, the share of these sectors decreased by 20.1 percentage points to $52.0 \%$. In contrast, the shares of the remaining subsectors increased, except for the Central bank subsector (S121). The shares of the added value of the subsectors of other financial intermediaries and insurance corporations have grown the most by $11.3 \%$ and $7.1 \%$ respectively. It is noteworthy that lowering of the role of commercial banks as financial intermediaries and enlarging the impact of nonbanking financial institutions and institutional investors were also observed in international financial markets due to financialization processes [20].

The last decade was extremely challenging for Ukrainian banks. The subsector of domestic Deposit-taking corporations was hard hit by the 2008 crisis and other adverse circumstances of the 2014-2016 period. As we can see in the diagram (Figure 3), there are 193 banks included in the State Register of Banks in 2006, and $88.1 \%$ of them had a banking license. The highest number of banks (198) in the State Register was in 2007, 2008 and 2011. There was the maximum quantity of banks which have a banking license $(99.4 \%)$ in 2012.
The total number of banks included in the State Register of Banks decreased by 30 banks or $15.2 \%$ in 2018 compared to the maximum value. At the same time, the number of banks which have a banking license decreased more significantly - by 106 banks or $57.6 \%$ in 2018 compared to the maximum (184) in 2008. The above has led to a reduction of licensed banks by $53 \%$ - from the extreme point in $2012(99.4 \%)$ to $46.4 \%$ at the end of the period under investigation. Thus, the scale of Ukraine's banking system decreased by more than 2 times in terms of the number of banking institutions.

As Belinska remarks, the causes of mass bank failures during 2014-2016 were external and internal [4, p. 37-38]. The main external causes are as follows: the country's economic situation; inflation; market reforms which are effective in the long run but can exacerbate the crisis processes in the banking system in the short run; a lack of customers' trust; raider attacks aimed to depreciate bank assets. Internal causes are as follows: the non-compliance with legislation; dishonesty of authorities; leadership incompetence; speculation; weaknesses of the internal banking system.

To overcome these problems, the Ukrainian authorities make efforts to improve the county's investment and innovative climate and transform the Ukrainian financial sector into a competitive environment with highly developed financial intermediation institutions. On January 16, 2020, the Strategy of Ukrainian Financial Sector Development until 2025 [11] was approved by the National Bank of Ukraine, the National Securities and Stock Market Commission, the National Commission for the State Regulation of Financial Services Markets, the Deposit Guarantee Fund

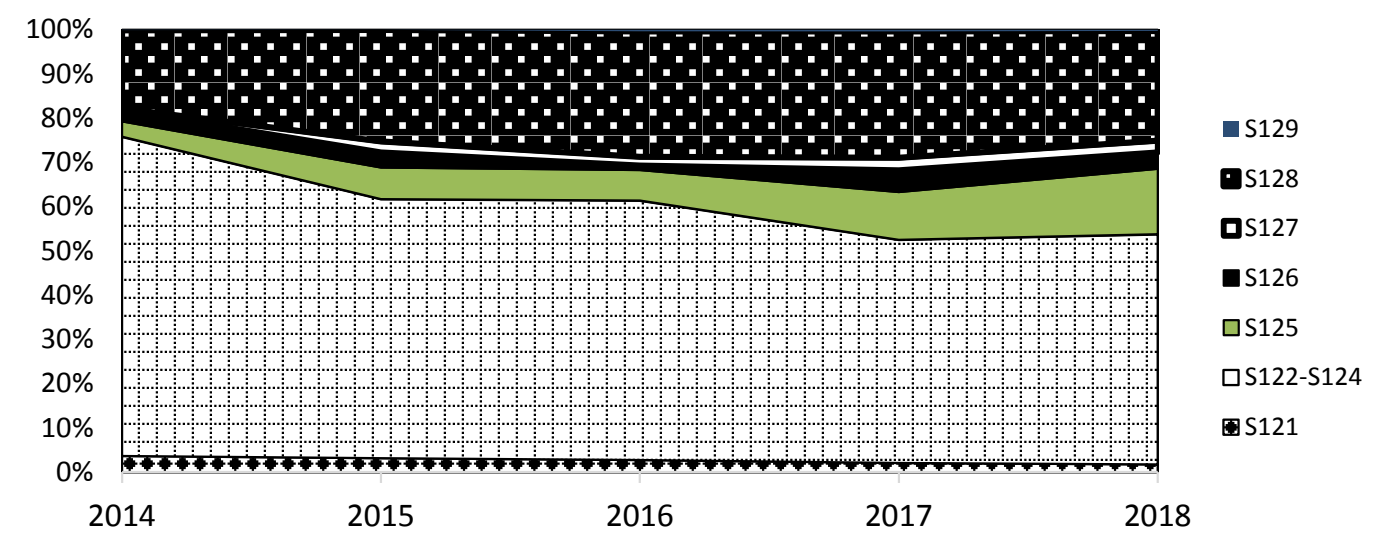

Figure. 2. Value-added structure of Ukrainian financial corporations' sector in 2014-2018

Source: build-up by the authors relying on the Figure 2 


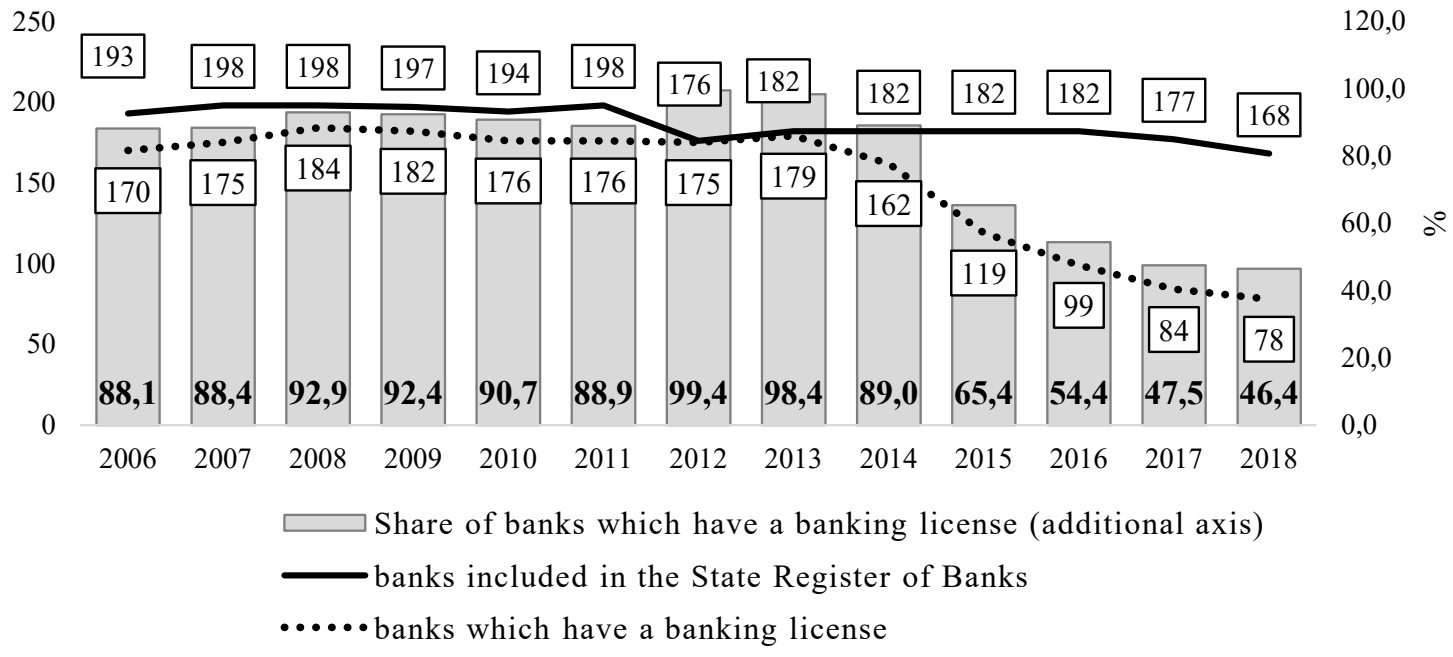

Figure 3. Quantity of banks in Ukraine in 2006-2018 (as of year-end)

Source: made by the authors relying on [12]

and the Ministry of Finance of Ukraine. The key points of the Strategy were formed by taking into account global trends and major tendencies of the Ukrainian economic development. The Strategy unites and synchronizes the actions of regulators and market participants. Generally, it will contribute to the establishment of a more efficient, transparent and reliable financial system in Ukraine which meets the best international standards.

Conclusion. The Ukrainian financial sector depends both on global trends and the internal situation in politics and economy. The external factors act mainly towards complicating the global financial system, improving financial instruments and increasing the importance of the technological component of financial activity. The internal factors cover the lasting effects of the 2008 financial crisis on the Ukrainian economy and the worsening economic situation caused by hostilities in the country.

This led to a decrease in the value-added of the financial corporations' sector in 2014-2016 and shifts in its structure at the level of subsectors. As Ukrainian bank system is the main part of the domestic financial sector, challenges in banks activity caused the reduction of sector's share in gross value added in 2015-2018 compared to 2014. In addition, the share of subsectors S122-124 in financial corporations' value-added declined by $20.1 \%$ in 2018 compared to 2014.

Measures taken by the Ukrainian authorities are aimed at improving the situation in the financial sector. The last significant milestone is the adoption of the Strategy of Ukrainian Financial Sector Development until 2025. This document was elaborated and approved by the National Bank of Ukraine, the National Securities and Stock Market Commission, the National Commission for State Regulation of Financial Services Markets, the Deposit Guarantee Fund and the Ministry of Finance of Ukraine. Its successful implementation would help achieve progress in the Ukrainian financial sector development.

\section{References:}

1. Acharya V., Philippon T., Richardson M., Roubini N. (2009) The financial crisis of 2007-2009: causes and remedies. Financial Markets, Institutions and Instruments, vol. 18, no. 2, pp. 89-137.

2. Ball R. (2009) The global financial crisis and the efficient market hypothesis: what have we learned? Journal of Applied Corporate Finance, vol. 21, no. 4, pp. 8-16.

3. Baranovskyi O. I. (2017) Substance of transformational processes in financial sector of national economy. Financial and credit activity: problems of theory and practice, vol. 2, no. 23, pp. 346-360. (in Ukrainian)

4. Belinska G. (2016) Current problems of banking system of Ukraine: causes and solutions. Finanse, accounting, banks, 1(21), 34-42. (in Ukrainian)

5. Christophers B. (2015) The Limits to Financialization. Dialogues in Human Geography, vol. 5, no. 2, pp. $183-200$.

6. Foster J. B., Magdoff F. (2009) The Great Financial Crisis: Causes and Consequences. New York: Monthly Review Press.

7. Kovalenko Yu. M. (2013) Institutialization of the financial sector. Irpin: NUSTS of Ukraine. (in Ukrainian)

8. Korneyev M. V. (2015) Methodological bases of evaluation and regulation of the financial resources movement imbalances in the economy of Ukraine (Doctoral dissertation). Sumy: Ukrainian Academy of Banking. (in Ukrainian)

9. Lagoarde-Segot T. (2017) Financialization: Towards a new research agenda. International Review of Financial Analysis, vol. 51, pp. 113-123.

10. Mader P., Mertens, D., Van der Zwan, N. (2020) Financialization: An Introduction. The Routledge International Handbook of Financialization. Abingdon: Routledge, pp. 1-16.

11. National Bank of Ukraine. Strategy of Ukrainian Financial Sector Development until 2025. Available at: https://bank.gov.ua/en/files/gmzinByGCNNglWc (accessed 09.08.2020).

12. National Bank of Ukraine. Monetary statistics: Selected data on deposit-taking corporations (excluding National bank of Ukraine). Available at: https://bank.gov.ua/en/statistic/sector-financial/data-sector-financial\#1ms (accessed 06.01.2020). 
13. Neuhauser K. L. (2015) The Global Financial Crisis: what have we learned so far? International Journal of Managerial Finance, vol. 11, no. 2, pp. 134-161.

14. Rose A., Spiegel M. M. (2010) Cross-country causes and consequences of the 2008 crisis: international linkages and American exposure. Pacific Economic Review, vol. 15, no. 3, pp. 340-363.

15. Russo A., Zanini, A. (2010) On the Expansion of Finance and Financialisation. MPRA Paper. No. 26828, Munich.

16. State Statistics Service of Ukraine (2020) National Accounts of Ukraine for 2018. Kyiv: Derzhanalitinform. (in Ukrainian)

17. Shkolnik I. O. (2008) Strategy of development of the financial market of Ukraine (Doctoral dissertation). Sumy: State Higher Educational Institution "Ukrainian Academy of Banking of National Bank of Ukraine". (in Ukrainian)

18. UN, European Commission, IMF, World Bank \& OECD (2009) System of National Accounts, 2008. New York.

19. Zadorozhna R. (2017) Perspectives and challenges of the financial sector development in the digital age. Proceedings of the Transformation of the national model of financial-credit relations: challenges of globalization and regional aspects (Ukraine, Uzhhorod, November 23, 2017). Uzhhorod: Hoverla, pp. 28-29.

20. Żelazny J. (2016) Financialization and commodity market stability. E-Finanse: Financial Internet Quarterly, vol. 12, no. 4 , pp. $33-42$. 